Atlas of the Transatlantic Slave Trade 
The Lewis Walpole Series in

Eighteenth-Century Culture and History

The Lewis Walpole Series, published by Yale University

Press with the aid of the Annie Burr Lewis Fund, is dedicated

to the culture and history of the long eighteenth century

(from the Glorious Revolution to the accession of Queen

Victoria). It welcomes work in a variety of fields, including

literature and history, the visual arts, political philosophy,

music, legal history, and the history of science. In addition to

original scholarly work, the series publishes new editions and

translations of writing from the period, as well as reprints

of major books that are currently unavailable. Though the

majority of books in the series will probably concentrate on

Great Britain and the Continent, the range of our geographi-

cal interests is as wide as Horace Walpole's. 


\title{
Atlas of the Transatlantic Slave Trade
}

\section{David Eltis and David Richardson}

Foreword by David Brion Davis

Afterword by David W. Blight

\author{
EDITORIAL BOARD \\ James G. Basker, Barnard College \\ David W. Blight, Yale University \\ David Brion Davis, Yale University \\ Cheryl Finley, Cornell University \\ Robert Harms, Yale University \\ Paul F. Lachance, University of Ottawa \\ Don Larson, Mapping Specialists, Ltd.
}

Yale UNIVERSITY PRESS

New Haven \& London 
Published with assistance from the Kingsley Trust Association Publication Fund established by the Scroll and Key Society of Yale College and with assistance from the Annie Burr Lewis Fund.

"Middle Passage." Copyright () 1962, 1966 by Robert Hayden, from Collected Poems of Robert Hayden, by Robert Hayden, edited by Frederick Glaysher. Used by permission of Liveright Publishing Corporation.

Copyright $\odot 2010$ by Yale University.

All rights reserved.

This book may not be reproduced, in whole or in part, including illustrations, in any form (beyond that copying permitted by Sections 107 and 108 of the U.S. Copyright Law and except by reviewers for the public press), without written permission from the publishers.

Yale University Press books may be purchased in quantity for educational, business, or promotional use. For information please e-mail sales.press@yale.edu (U.S. office) or sales@yaleup.co.uk (U.K. office).

Maps provided by Mapping Specialists, Ltd., Madison, Wisconsin. Designed by James J. Johnson. Set in Adobe Minion type by Julie Allred, BW\&A Books, Inc. Durham, North Carolina.

Printed in China.
Library of Congress Cataloging-in-Publication Data Eltis, David, 1940-

Atlas of the transatlantic slave trade / David Eltis and David Richardson ; foreword by David Brion Davis ; afterword by David W. Blight.

p. cm. - (The Lewis Walpole series in eighteenth-century culture and history)

ISBN 978-0-300-12460-6 (alk. paper) 1. Slave trade-Africa-History-

Maps. I. Richardson, David, 1946II. Title. III. Title: Trans-Atlantic slave trade.

G2445.E625.E4 2010

381'.44091821022-dc22

2010018285

A catalogue record for this book is available from the British Library.

This paper meets the requirements of ANSI/NISO Z39.48-1992 (Permanence of Paper).

10987654321 
Major support for the Atlas of the Transatlantic Slave Trade was provided by:

The Annie Burr Lewis Fund at Yale University

The Gilder Lehrman Institute of American History

The Gilder Lehrman Center for the Study of Slavery, Resistance, and Abolition

The Kingsley Trust Association Publication Fund at Yale University

The Papenfuse Foundation

The Wilberforce Institute for the Study of Slavery and Emancipation, University of Hull 
This page intentionally left blank 
TO THE MEMORY OF

\section{Philip DeArmond Curtin}

(1922-2009)

historian of Africa and the African diaspora,

whose work inspired the creation of the slave voyages

database upon which this atlas is based 
On this distressing subject, so revolting to every well regulated mind, I will add that such is the merciless treatment of the slaves by the persons engaged in the traffic that no fancy can picture the horror of the voyage-crowded together so as not to give the power to move-linked one to the other by the leg-never unfettered whilst life remains, or till the iron shall have fretted the flesh almost to the bone ... breathing an atmosphere the most putrid and pestilential possible, with little food and less water.... It is to me a matter of extreme wonder that any of these miserable people live the voyage through; many of them indeed perish on the passage, and those who remain to meet the shore, present a picture of wretchedness language cannot express.

"Report on the Coast of Africa made by Captain George Collier, 1818-19," pp. 241-242, Admiralty Library

Manuscript Collection, MSS 45, National Museum of the Royal Navy, Portsmouth. Published with permission of the National Museum of the Royal Navy, Portsmouth, England. We are grateful to Mary Wills for drawing this source to our attention. 